\title{
VENGIMO IŠLAIKYTI VAIKĄ BAUDŽIAMOJO TEISINIO VERTINIMO PROBLEMOS
}

\author{
Kristina Grinevičiūtè \\ Mykolo Romerio universiteto Teisès fakulteto \\ Baudžiamosios teisès ir proceso institutas \\ Ateities g. 20, LT-08303 Vilnius, Lietuva \\ Telefonas +370 52714584 \\ El. paštas: kristina.grineviciute@registrucentras.lt
}

Pateikta 2013 m. gegužès 22 d., parengta spausdinti 2014 m. rugsėjo 24 d.

doi:10.13165/SMS-14-6-2-11

Anotacija. Straipsnyje analizuojamas vengimo išlaikyti vaika nusikaltimas, numatytas Lietuvos Respublikos baudžiamojo kodekso 164 straipsnyje. Apžvelgiamas šio nusikaltimo atsiradimas baudžiamajame istatyme, analizuojami argumentai dèl tokios veikos kriminalizavimo pagristumo ir bütinumo. Autore pateikia nuomonę, jog baudžiamoji atsakomybe už tokia veika neprarado savo socialinés svarbos ir kriminalizavimas yra pagrịstas. Straipsnyje iškeliami vengimo išlaikyti vaika normos trūkumai, analizuojamas teisinis atsakomybès už ši nusikaltima reglamentavimas užsienio valstybiu istatymuose, pateikiami kriterijai, padesiantys aiškiau nustatyti bei motyvuoti baudžiamosios atsakomybès taikyma už vaiko išlaikymo pareigos nevykdymą. Teoriné analizè grindžiama teismu praktika. Atlikus teorinę ir teismu praktikos analizę, daroma išvada, kad norint pritaikyti BK 164 straipsnį turètu büti nustatomi papildomi kriterijai, sustiprinantys argumentus taikant baudžiamaja atsakomybe - kreditoriaus teisinès padèties apsunkinimo, žalos, kaltininko darbingumo, turtinés padèties ir kt. Straipsnyje pasiūlyti kylančiu nusikaltimo kvalifikavimo problemu sprendimo variantai.

Socialinių mokslų studijos / Societal Studies

(C) Mykolo Romerio universitetas, 2014

(C) Mykolas Romeris University, 2014
ISSN 2029-2244 (online)

http://www.mruni.eu/lt/mokslo_darbai/SMS/ http://www.mruni.eu/en/mokslo_darbai/SMS/ 
Reikšminiai žodžiai: vengimas, vaiko išlaikymas, vaikas, baudžiamoji atsakomy$b \dot{e}$, kriminalizavimas.

\section{Itvadas}

Lietuvos teisė numato baudžiamąją atsakomybę už vengimą išlaikyti vaiką. Vengimas išlaikyti vaiką (Lietuvos Respublikos baudžiamojo kodekso 164 straipsnis) laikomas nesunkiu nusikaltimu, už kurị numatyta griežčiausia bausmė yra laisvės atèmimas iki dvejų metų. Ši norma tiesiogiai kriminalizuoja civilinį teisinị pažeidimą, t. y. toks nusikaltimas leidžia bausti už skolas (ịsiskolinimą už vaiko išlaikymą, atsiradusị pagal teismo sprendimą). Teismo sprendimo išlaikyti vaiką nevykdymas praktikoje kelia daug klausimų, nes neaišku, nuo kurio momento asmuo jau turi būti traukiamas baudžiamojon atsakomybėn, o kada dar pakanka taikyti kitas poveikio priemones. Neaišku, kokie kriterijai lemia šios veikos pripažinimą nusikaltimu. Pažymètina, kad baudžiamoji atsakomybė už šį nusikaltimą taikoma dažnai, todèl šis faktas patvirtina šių klausimų aktualumą ir reikšmingumą. Palyginti su 2010 m., padaugèjo vaikų, nukentejjusių nuo vengimo išlaikyti vaikus (nuo 282 iki 405 (2012 m.), 397 (2013 m.). ${ }^{1}$ Lietuvoje pabrèžiama, kad tai opi socialinè problema ir kad veiksmingiausias kovos būdas yra baudžiamosios teisinès priemonès. ${ }^{2}$ Šio straipsnio autorès nuomone, kriminalinè bausmè nèra vaistas nuo kamuojančios socialinès problemos, todèl baudžiamosios atsakomybės už vengimą išlaikyti vaiką kriterijų nustatymas yra itin svarbus ir turi apsaugoti teisinių santykių dalyvius nuo nepagrissto jų veikų kriminalizavimo.

Straipsnyje analizuojama vengimo išlaikyti vaiką nusikaltimo baudžiamojo teisinio vertinimo problema. Straipsnio tikslas - taikant sisteminį, loginį, teismų praktikos analizės ir kitus tyrimo metodus nustatyti baudžiamosios atsakomybès už vengimą išlaikyti vaiką pagal teismo sprendimą kriterijus.

Reikia pripažinti, kad išsamaus teorinio vengimo išlaikyti vaiką vertinimo Lietuvos teisès doktrinoje nèra. Kaip išimtį galima paminèti L. Žalnieriūno ir T. Gir-

1 Statistiniai duomenys apie ikiteisminio tyrimo įstaigose $2013 \mathrm{~m}$. užregistruotus nukentẻjusius vaikus (iki 18 metų) pagal atskiras nusikalstamas veikas: BK 160-164 straipsniai. Informatikos ir ryšiu departamentas [interaktyvus]. Vilnius [žiūrèta 2014-03-07]. < http://www.ird. lt/infusions/report_manager/reports/txt_file.php?fv=data/1_201312_lt/f-50n-iti-201312. data.txt\&ff=\%3C!--|50N-ITI $|13|--\% 3 \mathrm{E} \& \mathrm{tt}=$ Duomenys\%20apie\%20ikiteisminio\%20tyrimo $\% 20 \%$ C $4 \%$ AFstaigose $\% 20 u \% C 5 \%$ BEregistruotus\%20nukent\%C4\%97jusius\%20vaikus\%20\%28iki\%2018\%20met\%C5\%B3\%29\%20\%3C\%2Fstrong\%3E\%28remiantis\%20 i \%C5\% A 1 ankstiniais $\% 20$ duomenimis $\% 29 \% 20 \% 3$ Cstrong $\% 3$ E $\% 28$ Forma_50NIT\%C4\%AE\%29 >.

2 Vaikų išlaikymo fondo įstatymo ex-post poveikio vertinimas. Lietuvos Respublikos Vyriausybe [interaktyvus]. Vilnius [žiūrèta 2013-06-26]. < http://www.lrv.lt/bylos/VORTprojektas/ Dokumentai/8-VIF\%20Vertinimas\%20final.pdf $>$. 
denio straipsnị ${ }^{3}$, kuriame iš dalies analizuojami probleminiai kvalifikavimo aspektai bei glaustai šio nusikaltimo požymiai, paaiškinti Baudžiamojo kodekso komentare ${ }^{4}$.

Vengimo išlaikyti vaiką kriminalizavimo probleminiai aspektai ir galimi problemos sprendimo būdai

Pareigos išlaikyti vaiką penalizacija įvyko tik XIX a. pabaigoje, kai pasikeite ir susilpnejo dominuojantis vyro statusas šeimoje. Keičiantis visuomenejje egzistuojančioms vertybėms, keičiasi ir valstybės reakcija ị tam tikrų vertybių apsaugą baudžiamosiomis teisinėmis priemonėmis. Vengimo išlaikyti vaiką normos istorinès ištakos sietinos su valstybès pastangomis užtikrinti normalų vaiko vystymąsi. Vaiko teisė i materialinị aprūpinimą yra viena pagrindinių vaiko teisių, be kurios tinkamo ịgyvendinimo neįmanoma normali vaiko raida. Nè viena pasaulio valstybė pati negali užtikrinti visiško visų vaikų materialinio aprūpinimo, todẻl šeimos nariai išlieka pagrindiniu vaikų materialinio aprūpinimo šaltiniu.

BK 164 straipsnyje ịtvirtintas nusikaltimas yra skirtas kovai su vengimu išlaikyti vaiką. Šio nusikaltimo turinị sudaro teismo sprendimo išlaikyti vaiką nevykdymas. Iš pirmo žvilgsnio toks baudžiamojo draudimo suformulavimas iš tikrųjų atrodo kaip labai paprasta ir efektyvi teisinè priemonè, nesukelianti didelių jos inkriminavimo problemų. Nepervedus léšų vaikui išlaikyti pagal teismo sprendimą vieną mėnesį, formaliai jau galima taikyti baudžiamąją atsakomybę už vengimą išlaikyti vaiką. Galima prognozuoti, kad taip greitai pritaikius šią normą visuomenè taptų kriminalinè. Pažymėtina, kad baudžiamajame įstatyme nenustatyta jokių požymių, kaip nors pabrèžiančių baudžiamosios atsakomybès taikymo pagrịstumą. Toks požiūris, manytina, nedera su paskutinès priemonès (lot. ultima ratio) principu baudžiamojoje teisèje ir kelia pagrịstų abejonių dèl tokios veikos kriminalizavimo.

Autorès nuomone, galimi du alternatyvūs vengimo išlaikyti vaiką normos nekonkretumo išvengim būdai. Pirma galimybè apskritai atsisakyti vengimo išlaikyti vaiką normos BK, kas reikštų veikos dekriminalizavimą. Tokiam žingsniui galima surasti nemažai argumentų. Ši norma tiesiogiai kriminalizuoja civilinį teisinị pažeidimą, t. y. toks nusikaltimas leidžia bausti už skolas. Paprastai, jei skolininkas prievolès nevykdo ar ją vykdo netinkamai, jam taikoma civilinė atsakomybė. Veiką dekriminalizuoti galima dèl to, kad šią socialinę problemą galima spręsti kitais būdais, t. y. taikant alternatyvias - civilinio poveikio, priemones. Be to, už ši nusikaltimą sunku numatyti tinkamas bausmių rūšis. Teisineje literaūroje pateikiama ir daugiau argumentų. Pavyzdžiui, teigiama, jog tokios veikos kriminalizavimas igalina greitai „gaminti“ nusikaltèlius ${ }^{5}$. Baudžiamoji teisinè represija už šị nusikaltimą mažai veiksmin-

3 Žr., pvz., Žalnieriūnas, L.; Girdenis, T. Vengimo išlaikyti vaiką probleminiai kvalifikavimo aspektai ir alternatyvūs normai instrumentai. Jurisprudencija. 2013, 20(2): 703-719.

4 Žr., pvz., Abramavičius, A., et al. Lietuvos Respublikos baudžiamojo kodekso komentaras. Specialioji dalis (99-212 straipsniai). Vilnius: VIt Registrų centras, 2009, p. 225-227.

5 Žr., pvz., Kolakowska-Przelomiec, H. Przestępstwa niealimentacji - studium kryminologiczne. Wrocław: zakład Narodowy im. Ossolińskich, 1989, p. 153. 
ga, dažniau tik paaštrina konfliktą šeimoje ir sudaro sąlygas toliau vengti pareigos ${ }^{6}$. Kova su vengimu išlaikyti vaiką baudžiamosiomis teisinèmis priemonèmis neefektyvi, o kitos teisinès priemonès neišnaudojamos, kadangi taikoma kriminalinė bausmè. Sankcijoje numatytos bausmių rūšys negali užtikrinti pozityvių kriminalizacijos padarinių ${ }^{7}$. Neracionalu bausti už vengimą išlaikyti vaiką laisvès atėmimo bausme, atsižvelgiant ị didelius bausmès iggyvendinimo kaštus. Atitinkamai laisvès atėmimo bausmès paskyrimas sumažina galimybę kaltininkui vykdyti pareigą išlaikyti vaiką ir tik didina ịsiskolinimą. Laisvès atėmimo bausmès paskyrimas reiškia, kad asmuo nedirbs ir neturès galimybès uždirbti pinigų, o teistumas sumažina galimybę ịsidarbinti vèliau. Asmens izoliavimas nuo visuomenès susilpnina ryši su vaikais ir šeimos nariais. Taip pat padidina tikimybę, jog asmuo nusikals pakartotinai ${ }^{8}$.

Vengimas išlaikyti vaiką yra prievolès nevykdymas, todèl šios veikos kriminalizavimas gali atrodyti kaip baudžiamosios teisès žengimas ị civilistiką. Tačiau baudžiamos atsakomybės už vengimą išlaikyti vaiką šalininkai teigia, kad toks procesas yra natūralus, nes netinkamas teisių ir pareigų ígyvendinimas gali būti toks pat pavojingas, kaip elementari vagysté, o tokio elgesio padarytą žalą gali būti labai sunku kompensuoti vien tik civilinėmis teisinėmis priemonėmis. Be to, nebelikus vengimo išlaikyti vaiką normos liktų spraga, kurios negalima būtų vertinti pasitelkiant kitas BK normas (išskyrus, BK 245 straipsnị (teismo sprendimo, nesusijusio su bausme, nevykdymas), kurị taip pat siūloma dekriminalizuoti ${ }^{9}$ ). Atsisakius baudžiamosios atsakomybės pablogètų nukentėjusiųjų vaikų padètis, nes kitos poveikio priemonès ne visada yra veiksmingos.

Autorès nuomone, esminè problema yra ne vengimo išlaikyti vaiką penalizacija, o baudžiamosios atsakomybės taikymo ribų nustatymas. Būtina sukonkretinti vengimo išlaikyti nusikaltimo požymius, pateikiant aiškesnius baudžiamosios atsakomybės taikymo kriterijus. Pavyzdžiui, suformuluoti padarinius, kurie informatyviai rodytų vengimo išlaikyti vaiką nusikalstamą pobūdị ir atribotų šią veiką nuo civilinès teisės pažeidimo, arba sukonkretinti (kartu ir susiaurinti) vengimo išlaikyti vaiką sudètị pavojingo veikimo laikotarpiu, t. y. šie požymiai galètų tapti būtinais pagrindinès sudèties požymiais ar kt. Šių kriterijų tinkamumas toliau aptariamas plačiau.

$6 \quad$ Žr., pvz., Siwik, Z. Przestepstwo niealimentacji ze stanowiska polityki kryminalnej. Wrocław: Państwowe Wydawn. Nauk., 1974, p. 40.

7 Žr., pvz., Ermolaev, A. V. Ugolovnaja otvestvennost za prestuplenija protiv semi: problemy zakonodatelnoj reglamentacii i pravoprimenenija i puti ik razreshenija. Avtoreferat dissertacii. [Criminal responsibility for crimes against the family: the problems of legislative regulation and enforcement, and ways of solving them]. Krasnodar, 2009.

$8 \quad$ Žr., pvz., Solomon-Fears, C.; Smith, A. M.; Berry, C. Child Support Enforcement: Incarceration As the Last Resort Penalty For Nonpayment of Support. The Green Book [interaktyvus]. [žiūrèta 2013-07-24]. <http://greenbook.waysandmeans.house.gov/sites/greenbook.waysandmeans. house.gov/files/2012/documents/R42389_gb.pdf>.

9 Žr., pvz., Pranka, D. Nusikalstamos veikos ir civilinès teisès pažeidimo atribojimo koncepcija Lietuvos baudžiamojoje teisèje. Daktaro disertacija. Socialiniai mokslai (teisè). Vilnius: Mykolo Romerio universitetas, 2012, p. 126. 


\section{Vengimo išlaikyti vaiką nusikaltimo atribojimo kriterijai užsienio valstybių teisèje}

Vengimo išlaikyti vaiką norma Lietuvoje vystèsi sovietinèje teiseje. Kriterijus, skiriantis nusikalstamą vengimą išlaikyti vaiką nuo nenusikalstamo, buvo piktybiškumo požymis. Vengimo piktybiškumą kiekvienu konkrečiu atveju nustatydavo ir įvertindavo teismas. Piktybiškumas buvo nustatomas pagal veikos trukmę (ji turi tęstis ilgesnị laiką), veikos sistemingumą ir pakartotinumą, pagal kaltininko elgeși ir jo psichini santykị su veika (numatytas neigiamas psichinis santykis su pareiga (teismo sprendimo atviras ignoravimas, atsisakymas ji vykdyti), pagal objektyvią galimybę i̇vykdyti pareigą ir t. t. ${ }^{10}$

Dabar galiojančiame BK atsisakyta itin daug diskusiju kèlusio vertinamojo požymio „piktybinio“ vengimo mokèti lěšas vaikams išlaikyti, tačiau jokių papildomų požymių įstatymų leidejjas neịtvirtino. Autore drịsta teigti, kad vengimo požymis nesukuria kriminalizavimui būtino informatyvumo ir neatsako ị klausimą, koks elgesys yra uždraustas ir už jị baudžiama. Norma sukonstruota labai abstrakčiai, nes vengimo požymis nèra didesnio veikos pavojingumo kriterijus.

Užsienio valstybiu baudžiamojoje teisẻje bandymai atriboti vengimo išlaikyti vaiką nusikaltimą ir civilinès teisès pažeidimą labai ịvairūs. Baudžiamieji ịstatymai nustato gana skirtingus kriterijus, kurie, jų manymu, turètų padèti išspręsti nagrinèjamą atribojimo problemą. Pavyzdžiui, Rusijos $\mathrm{BK}^{11}$ ir jos teisinès tradicijos paveiktose šalyse (Ukrainos $\mathrm{BK}^{12}$, Latvijos $\mathrm{BK}{ }^{13}$, Estijos $\mathrm{BK}^{14}$ ir kt.) vengimo išlaikyti vaiką normose išliko įtvirtintas piktybiškumo požymis. Ukrainos įstatymų leidejjas pačiame BK pateikia šio požymio išaiškinimą. Piktybišku vengimu išlaikyti vaiką laikomi bet kokie kaltininko veiksmai, nukreipti ị teismo sprendimo nevykdymą (pajamų slèpimas, gyvenamosios vietos ar darbo pakeitimas, be valstybès išieškotojo pritarimo ar kt.), kai įsiskolinimas yra ne mažiau kaip už šešis mėnesius. Kaip minèta, piktybiškumo požymis aiškinamas per veikos sistemingumą, trukimą ilgą laiką ir pakartotinumą, kaltininko psichinị santykị su veika. Literatūroje nurodomi ir kiti piktybiškumo nustatymo kriterijai, pavyzdžiui, tai gali būti valstybès igaliotos institucijos priminimas apie pareigą, dalinio mokèjimo periodiškumas, ịsiskolinimo dydis ${ }^{15} \mathrm{ir} / \mathrm{ar}$ kt.

10 Žr., pvz., Tarybinè baudžiamoji teisè. Ypatingoji dalis. Vilnius: Mintis, 1974, p. 119.

11 Ugolovnyj kodeks Rossijskoj Federacii. [Criminal Code of the Russian Federation] [interaktyvus]. [žiūrèta 2013-07-04] <http://www.legislationline.org/ru/documents/action/ popup/id/16287/preview $>$.

12 Ugolovnyj kodeks Ukrainy [Criminal Code of Ukraina] [interaktyvus]. [žiūrèta 2013-07-04]. $<$ http://kodeksy.com.ua/ka/ugolovnyj_kodeks_ukraini/statja-164.htm>.

13 Criminal Code of the Republic of Latvia [interaktyvus]. [žiūrèta 2013-07-04]. < http://legislationline.org/documents/section/criminal-codes $>$.

14 Criminal Code of the Republic of Estonia [interaktyvus]. [žiūrèta 2013-07-04]. < http://legislationline.org/documents/section/criminal-codes $>$. Žr., pvz., Bernikov, P. V. Ugolovnaja otvestvennost za neuplatu alimentov kak zashhita prav che- 
Vakarų Europos valstybių baudžiamuosiuose ịstatymuose, pavyzdžiui, pagal Lenkijos $^{16}$, Vokietijos ${ }^{17}$, Austrijos ${ }^{18}$ ir kt., nusikalstamą veikos pobūdį rodo dispozicijoje suformuluoti padariniai: negalëjimas patenkinti būtinų gyvenimo poreikių (Lenkijos BK 209 str. 1 d.); grèsmė gyvenimiškiems poreikiams (Vokietijos BK 170 str., Austrijos BK 198 str. 1 d.). Išlaikymo pareiga privalo būti vykdoma siekiant užtikrinti, jog asmuo gaudamas išlaikymą galès patenkinti būtiniausius gyvenimo poreikius. Gyvenimiški poreikiai suprantami plačiąja prasme, tai ne tik minimalių (fiziologinių) poreikių patenkinimas, bet ir sudarymas materialinių sąlygų fiziškai ir socialiai vystytis, igyti išsilavinimą ir t. t. ${ }^{19}$ Grèsmė gyvenimiškiems poreikiams nustatoma, jei kiti asmenys turi prisiimti kaltininko pareigas. Taip pat tais atvejais, kai asmuo, turintis teisę gauti išlaikymą, turi dèti pernelyg dideles pastangas, siekdamas ịgyvendinti savo gyvenimo poreikius. Tačiau grèsmè gyvenimiškiems poreikiams nebus nustatoma, jei kaltininkas pagal savo galimybes gali teikti išlaikymą nežymiomis sumomis ${ }^{20}$. Grèsmé nustatoma ir tais atvejais, kai nukentejjusiojo gyvenimas gali pablogèti, pavyzdžiui, reikia priverstinai išsikelti iš buto, atsisakyti išsilavinimo ir t. t. ${ }^{21}$

Belgijos BK ${ }^{22}$ 425-427 straipsniai ši nusikaltimą sieja su grèsme vaiko sveikatai. Atitinkamų padarinių sukèlimas (pvz., susargdinimas nepagydoma liga, kurio nors organo funkcijų netekimas ir kt.) yra veiką kvalifikuojantys požymiai. Žala psichinei ar fizinei sveikatai arba mirtis, kaip kvalifikuojantis šios veikos požymis, yra numatyti ir Austrijos $\mathrm{BK}^{23}$.

loveka [Criminal liability for failure to pay child support as protection of human rights]. [interaktyvus]. [žiūrèta 2013-07-04]. <http://www.law.edu.ru/doc/document.asp?docID=1193708>; Kanteeva, E. V. Aktualnye problemy pravoprimenitelnoj praktiki pri vyjavlenii i prizvodstve doznanija po prestuplenijam, predusmotrennym st. 157 Ugolovnogo kodeksa Rossijskoj Federacii (na primere Respubliki Mordovija). Vestnik Cheljabinskogo gosudarstvennogo universiteta. [Bulletin of the Chelyabinsk State University]. 2013, 5 (296: 78-83.

16 Criminal Code of the Republic Poland [interaktyvus]. [žiūrèta 2011-10-20]. <http://www.legislationline.org/ru/documents/action/popup/id/16287/preview $>$.

17 Criminal Code of the Federal Republic of Germany [interaktyvus]. [žiūrèta 2011-10-20] $<$ http://www.gesetze-im-internet.de/englisch_stgb/englisch_stgb.html\#StGBengl_000P171>.

18 Österreich Strafgesetzbuch [interaktyvus]. [žiūrèta 2011-10-20]. <http://www.jusline.at/ Strafgesetzbuch_(StGB).html>.

19 Žr., pvz., Kodeks karny. Część szczególna. Tom I. Komentarz do artykułów 117-221. Pod redakcją A. Wąska, R. Zawłockiego. Wydawnictwo C. H. Beck, 2010, p. 1248-1251.

20 Žr., pvz., Zimmermann, H. Strafanzeige wegen Unterhaltspflichtverletzung (\$ 170 Strafgesetzbuch - StGB) als Mittel der Durchsetz ung von Unterhaltsansprüchen? [interaktyvus]. [žiūrèta 2013-07-24]. <http://www.zimmermann-strecker.de/themen/pdf/2008_12_Unterhaltspflichtverletzung.pdf $>$.

21 Žr., pvz., Bertel, Ch.; Schwaighofer, K. Österreichisches Strafrecht Besonderer Teil II (\$\$ 169 bis 321 StGB). Wien, NewYork: Springer, 2010, p. 55.

22 Ugolovnyj kodeks Belgii. [Criminal Code of Belgium]. Sankt-Peterburg: juridicheskij centr press, 2004.

23 Österreich Strafgesetzbuch [interaktyvus]. [žiūrèta 2011-10-20]. <http://www.jusline.at/ Strafgesetzbuch_(StGB).html>. 
Lenkijos BK 209 straipsnio dispozicijoje, be padarinių, dar įtvirtintas ir atkaklumo (lenk. uporczywosc) požymis. Šis požymis doktrinoje aiškinamas dvejopai. Pagal objektyviąją doktriną yra akcentuojamas veikos pakartotinumas, veikos trukimas ilgą laiką, nepaisant raginimų, priminimų ir t. t. Vyraujantis požiūris yra objektyvusissubjektyvusis, pagal kurị šis požymis apima tiek kaltininko elgesị (veikos kartotinumą, ilgumą, nenutrūkimą), tiek jo psichines nuostatas (užsispyrimą, piktą valią) ${ }^{24}$. Austrijos BK 198 straipsnio dispozicijoje papildomai ịtvirtintas šiurkštaus pareigos pažeidimo požymis. Nusikaltimu laikoma veika, kai susiduriama su visiškai nepriimtinu elgesiu. Šis požymis aiškai parodo disproporciją tarp reikalaujamos išlaikymo pareigos ir galimybès ją vykdyti, taip pat jis aiškinamas per veikos trukmę $e^{25}$.

Vengimas išlaikyti vaiką, kaip trunkamasis nusikaltimas, suponuoja, kad jis trunka tam tikrą laiką, yra sistemingas. Kai kurios užsienio valstybės tiesiogiai įtvirtina tokias nuostatas ir eliminuoja menamus požymius. Pavyzdžiui, Prancūzijos BK 227-3 straipsnis ${ }^{26}$ numato atsakomybę už alimentinių pareigų nevykdymą daugiau kaip du mènesius. Baltarusijos BK ${ }^{27} 174$ straipsnyje veikos baudžiamumas siejamas su nemokejjimu tris ménesius per metus, Slovakijos BK ${ }^{28} 207$ straipsnyje numatyta atsakomybė už pareigos išlaikyti vaiką nevykdymą mažiausiai tris mėnesius per dvejus metus. Maltos $\mathrm{BK}^{29} 338$ (z) straipsnyje įtvirtintas veikos baudžiamumas praejjus šešiems mėnesiams. Itvairių šalių baudžiamosios teisės doktrinoje šiuo klausimu taip pat pateikiami skirtingi požiūriai: kaltininkas traukiamas atsakomybèn, jeigu neteikia išlaikymo daugiau kaip šešis mėnesius arba atitinkamai ilgesnị laikotarpi teikia tik iš dalies ${ }^{30}$; pareigos nevykdymas bent tris mènesius arba mokejjimas nereguliariai arba mažiau, nei nurodyta teismo sprendime, jau sudaro objektyviuosius nusikaltimo požymius; pareigos išlaikyti vaiką nevykdymas du mėnesius neužtraukia baudžiamosios atsakomybės ${ }^{31}$; tris mènesius per metus nemoka alimentų arba moka tik jų dalį ${ }^{32}$; piktybišku vengimu išlaikyti vaiką laikomi periodai nuo keturių mėnesių, jei buvo

24 Žr., pvz., supra note 19, p. 1247-1248.

25 Žr., pvz., Bertel, Ch.; Schwaighofer, K., supra note 21, p. 53-55.

26 Criminal Code of the French Republic [interaktyvus]. [žiūrèta 2013-07-04]. <http://www.legislationline.org/documents/section/criminal-codes $>$.

27 Ugolovnyj kodeks Respubliki Belarus [Criminal Code of the Republic of Belarus]. [interaktyvus]. [žiūrèta 2013-07-04]. < http://www.wipo.int/wipolex/en/details.jsp?id=10048>.

28 Criminal Code of the Slovak Republic [interaktyvus]. [žiūrèta 2013-07-04]. < http://legislationline.org/documents/section/criminal-codes $>$.

29 Criminal Code of the Republic of Malta [interaktyvus]. [žiūrèta 2013-07-04]. < http://legislationline.org/documents/section/criminal-codes $>$.

30 Žr., pvz., Bertel, Ch.; Schwaighofer, K., supra note 21, p. 53-55.

31 Žr., pvz., supra note 19, p. 1247-1248.

32 Žr., pvz., Pudovochkin, Ju. E. Otvetstvennost za prestuplenija protiv nesovershennoletnik po Rossijskomu ugolovnomu pravu. [Responsibility for crimes against minors under Russian criminal law]. Санкт-Петербург, 2002, p. 204; Lietuvos TSR baudžiamojo kodekso komentaras. Vilnius: Mintis, 1989, p. 222. 
du rašytiniai perspėjimai apie baudžiamąją atsakomybę už veikąa ir kt. Iš autorès išanalizuotos Lietuvos teismų praktikos matyti, kad šis, vyraujantis požymis didelių nesklandumą nekelia, nes dažniausiai asmenys traukiami baudžiamojon atsakomybẻn už teismo sprendimo nevykdymą tikrai ilgą laikotarpị. Nustatyta, kad minimaliausia veikos trukmè, už kurią taikyta baudžiamoji atsakomybė, yra šeši mėnesiai ${ }^{34}$, nors teismų sprendimuose galima aptikti ir kitokias išsakytas pozicijas, pavyzdžiui, ilgu laiku laikytini atvejai, kai kaltininkas tris mènesius iš eilès arba tris mènesius per metus vengia moketti alimentus arba moka tik dali jü $u^{35}$.

Kalbant apie užsienio šalių baudžiamuosius ịstatymus, pasakytina, kad vengimo išlaikyti vaiką nusikaltimą nuo civilinès teisès delikto atriboja kaltès forma ir / arba padariniai, tam tikrais atvejais papildomai numatoma veikos trukmé arba veikos padarymo būdas. Iš esmès šie kriterijai susipina tarpusavyje. Pavyzdžiui, pati veikos trukmé, kaip kriterijus, nèra socialiai žalingas. Tačiau jeigu veikos trukmé pasirenkma kaip nusikaltimo padarymo būdas, tai jau bus aplinkybè, lemianti nusikaltimo pavojingumo laipsnị. Tiek nusikalstama veika, tiek civilinès teisès pažeidimu gali būti sukeliami įvairaus dydžio ir pobūdžio padariniai, todèl šiuo atveju ne jų buvimas ar dydis lemia pavojingumo laipsnị, bet tai, kokiu būdu šie padariniai atsirado. Reiškia, pavojingumo laipsniui reikšmès turi tai, koks būdas pasirinktas padariniams sukelti ir pan.

\section{Vengimo išlaikyti vaiką vertinimas lietuvos teismų praktikoje}

Kai kurie užsienio valstybių baudžiamuosiuse įstatymuose įtvirtinti vengimo išlaikyti vaiką atribojimo kriterijai yra plačiai taikomi ir Lietuvos teismų praktikoje, nors šie kriterijai doktrinoje ir teismų praktikoje nẻra aiškiai apibežiami ir išryškinami. Lietuvos baudžiamosios teisès doktrinoje kaip esminiai baudžiamosios atsakomybės už šį nusikaltimą taikymo kriterijai nurodomi - objektyvi galimybė vykdyti teismo sprendimą ir kreditoriaus teisinès padėties apsunkinimo kriterijus. Kreditoriaus teisinès padèties apsunkinimo kriterijus aiškinamas kaip situacija, kai kreditorius negali užtikrinti pareigos vykdymo civilinėmis procesinėmis priemonėmis arba kai tokios galimybės yra apsunkintos dèl skolininko nesąžiningų veiksmų: jis slepiasi, slepia savo pajamas, simuliuoja ligą, išpardave savo nekilnojamąji turtą, iš kurio galètų būti užtikrintas pareigos vykdymas, ir pan. ${ }^{36}$ Jeigu pareigos išlaikyti vaiką vykdymą i̇manoma užtikrinti civiline tvarka, baudžiamoji atsakomybè netaikytina. Baudžiamą-

33 Žr., pvz., Kanteeva, E. V., supra note 15, 78-83.

34 Žr., pvz., Kauno apygardos teismo Baudžiamụjų bylų skyriaus teisejjų kolegijos 2012-06-12 nutartis baudžiamojoje byloje (bylos Nr. 1A-385-397/2012).

35 Žr., pvz., Panevėžio apygardos teismo 2009-08-12 nutartis baudžiamojoje byloje (bylos Nr. 1S604-349/2009).

36 Žr., pvz., Fedosiuk, O. Paskaitų tezés [interaktyvus]. [žiūrèta 2013-07-04]. <http://www.mruni. lt/lt/TF_btk.htm>. 
ją atsakomybę už vengimą išlaikyti vaiką reikia sieti su kreditoriaus realių galimybių igyvendinti savo teisę civilinėmis teisinėmis priemonėmis sumenkinimu. Sąmoningą kreditoriaus galimybių sumenkinimą (apsunkinimą) reikètų laikyti būtinu elementu. Kitaip sakant, vengti išlaikyti vaiką reiškia ne tik neteisètai atsisakyti įvykdyti pareigą pagal teismo sprendimą, bet ir sudaryti padèti, kai tikètis pareigos išlaikyti vaiką vykdymo civilinèmis teisinèmis priemonèmis neįmanoma dẻl sąmoningų neteisètų skolininko veiksmų. Šis kriterijus didesnių aiškinimo probemų nekelia. Išanalizuota teismų praktika leidžia daryti išvadą, kad teismai vertina, ar buvo pasinaudota civilinėmis teisinėmis galimybėmis, nors pasitaiko ir kritikuotinų pavyzdžių:

M. V. nuteistas pagal BK 164 straipsni už tai, kad nevykde pareigos teikti visa teismo priteista išlaikyma vaikui nuo teismo sprendimo dienos (2010-05-13) iki tol, kol 6012,00 Lt isiskolinimas buvo išieškotas civilinio proceso tvarka (2012-02-15). Nuteistasis teige, kad jo baudžiamają atsakomybę anuliuoja faktas, jog jis neslépé turto, $j$ kurị civilinio proceso tvarka buvo galima nukreipti išlaikymo vaikui ịsiskolinimo išieškojima. Nurodè, kad antstoliu iniciatyva buvo areštuotas jo turtas (butas ir automobilis), t. y. jo įsiskolinimas buvo užtikrintas net 20 kartu didesne verte. Vèliau 6012,00 Lt įsiskolinimas buvo padengtas. Teismas konstatavo, kad tyčinis neteikimas vaikui išlaikymo, turint pajamu, jau yra pakankamas pagrindas baudžiamajai atsakomybei kilti. Tai, kad vaiko mama pasinaudojo galimybe savo pažeistas teises apginti civilinio proceso tvarka, nepašalina baudžiamosios atsakomybés ${ }^{37}$.

Autorès nuomone, teismas turèjo atkreipti daugiau dèmesio ị civilinès atsakomybės už šią veiką veiksmingumą. Baudžiamoji atsakomybė yra kraštutinė, paskutiné priemonè (ultima ratio), naudojama saugomų teisinių gèrių, vertybių apsaugai tais atvejais, kai švelnesnèmis priemonėmis tų pačių tikslų negalima pasiekti. Remiantis pavyzdžio aplinkybėmis, nèra jokio pagrindo teigti, kad kaltininko veika negali būti vertintina kaip civilinès teisès pažeidimas, nes pažeisti interesai buvo apginti civilinio proceso tvarka. Pats savaime pinigų nepervedimas laiku dar nėra vengimas.

Kreditoriaus teisinès padèties apsunkinimo kriterijus pasižymi sąmoningais ir neteisètais kaltininko (skolininko) veiksmais. Kai vengiama îvykdyti turtines prievoles, svarbiausia nustatyti, kiek kaltininkas savo sąmoningais veiksmais sumenkino kreditoriaus galimybes atkurti teisę civilinėmis teisinėmis priemonèmis. Logine, gramatine prasme žodis „vengimas“ reiškia stengimąsi išsisukti, išsisukinèjimą, tai yra tam tikri aktyvūs veiksmai ar aktyvus pareigos nevykdymas. Vengimo išlaikyti vaiką tikslai ịstatymo dispozicijoje nèra nurodyti, tačiau pagal pažeidimų esmę, jų padarymo kaltès turinị bei kitas aplinkybes galima spręsti, kad kaltininkas savo veika siekia išvengti (ar apskritai, ar kurị laiką) savo pareigos išlaikyti vaiką atlikimo. Kaltininkas sąmoningai nevykdo įsipareigojimo (nustatytais terminais nemoka lèšų, perveda mažesnes sumas, perleidžia turtą, keičia gyvenamąją vietą, nesuteikdamas apie tai informacijos, ir pan.). Pavyzdžiui:

37 Žr., pvz., Šiaulių apygardos teismo Baudžiamụjų bylų skyriaus teisèjų kolegijos 2012-12-27 nutartis baudžiamojoje byloje (bylos Nr. 1A-1212-152/2012). 
Kaltinamojo veiksmai, kai jis, büdamas bendrovés direktoriumi ir atlikdamas darbus už atlygì, ši atlygi slepia oficialioje buhalterijoje nefiksuodamas pajamų, be to, nieko nedarydamas, kad jo draugui perduoti pinigai būtų grą̌zinti jam, nesiimdamas priemoniu parduoti įkeistą nekilnojamaji turta, sąmoningai sudare situacija, dèl kurios tapo neįmanomas net ir priverstinis išlaikymo vaikams lěšu išieškojimas ${ }^{38}$.

Kreditoriaus teisinès padèties apsunkinimas - tai pagrindinis kriterijus, kuris turi būti nustatytas visais atvejais pripažistant, kad buvo padarytas vengimo išlaikyti vaiką nusikaltimas. Lietuvos teismų praktikoje palaipsniui ịtvirtinami ir kiti kriterijai, kurie padeda nustatyti, ar kaltininkas turi objektyvias galimybes ívykdyti teismo sprendimą, atsižvelgiant ị kaltininko savybes ir veiksmus. Iš esmès teismui kyla pareiga kiekvienu konkrečiu atveju nustatyti pareigos nevykdymo priežastis. Čia ịstatymų leidèjas teismui paliko erdvę vertinti konkrečias situacijas.

Pakankamai svarbiu kriterijumi laikomas kaltininko darbingumas. Pakanka to, kad kaltininkas yra pajėgus dirbti ir dirbdamas gali igyti pajamų. Be šio kriterijaus, Lietuvos teismai lygiaverčiai taiko ir pajamu ivertinimo metoda, kuris sustiprina argumentaciją priimant vieną ar kitą sprendimą. Tai reiškia, kad teismų praktikoje ivvertinama, kokios yra kaltininko galimybès, perspektyvos, pasirengimas ir noras pakeisti, pagerinti savo turtinę padètį, kad pavyktų vykdyti teismo sprendimą išlaikyti vaiką. Pavyzdžiui, vienoje byloje teismas, kaltinamąji pripažindamas kaltu, padarius nusikaltimą, numatytą BK 164 straipsnyje, kaip tik ir atsižvelgè ị tai, jog kaltinamasis yra darbingas asmuo, igijęs aukštesnijj išsilavinima, turi specialybę, todèl turi realias galimybes dirbti ir išlaikyti savo vaikus. Kaltinamasis nuolatos nesiregistruoja darbo biržoje, aktyviai nesiekia issidarbinti ar kitu büdu gauti pajamu (pvz., dirbant pagal verslo liudijima $)^{39}$. Šio kriterijaus esmè - teismas baudžiamąją atsakomybę grindžia pajamomis, kurias kaltininkas, atsižvelgiant ị išsilavinimą bei profesinị pasirengimą, turètų gauti, nors iš tikrųjų taip nèra. Tokio kriterijaus poreikis kyla, kai kaltininkas tyčia nesiima priemonių, kad gautų atitinkančias savo išsilavinimą ir profesinị pasirengimą pajamas (pvz., tyčia nedirba), iš kurių būtų teikiamas išlaikymas vaikui. Tiesa, šio kriterijaus negalima taikyti besąlygiškai. Kai egzistuoja svarbios priežastys, užkertančios kelią gauti didesnes pajamas (pvz., liga), šis kriterijus netaikytinas. Pavyzdžiui, vienoje byloje būtent dèl to fakto, jog kaltininkas pats yra iš dalies darbingas (35 proc.), siūlymu isidarbinti neturèjo, gauna itin mažas pajamas, buvo išteisintas

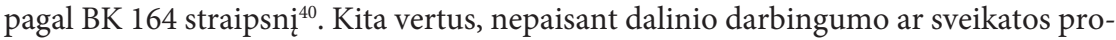
blemų, teismai priima apkaltinamuosius nuosprendžius, atsižvelgdami ị tai, kad silpna sveikata ir ligos nesutrukde daryti kitus nusikaltimus (vagystes) bei laikytis ydingo

38 Vilniaus miesto 1 apylinkès teismo 2012-05-17 nuosprendis baudžiamojoje byloje (bylos Nr. 1-769-654/2012).

39 Varènos rajono apylinkès teismo 2013-05-30 nuosprendis baudžiamojoje byloje (bylos Nr. 1-48-445/2013).

40 Vilniaus apygardos teismo Baudžiamųjų bylų skyriaus teisèjų kolegijos 2013-02-26 nuosprendis baudžiamojoje byloje (bylos Nr. 1A-203-92/2013). 
gyvenimo būdo (vartoti narkotikus, piktnaudžiauti alkoholiu) ${ }^{41}$; kaltininkas A. I. iš dalies darbingas (darbingumas 55 proc.), o tai reiškia, kad jis gali dirbti atitinkama darba pagal savo sveikatos būklę ${ }^{42}$. Aplinkybè, kad asmuo neteko dalies darbingumo, ne visais atvejais bus svarbia teismo sprendimo išlaikyti vaiką nevykdymo priežastimi. Teismas kiekvienu konkrečiu atveju turi įvertinti kaltininko sveikatos būklę ir galimybę dirbti jo sveikatos būklę atitinkantị darbą ir jeigu padaroma išvada, kad kaltininkas turi galimybę susirasti darbą ir tokiu būdu gauti pajamų bei dalị jų skirti vaikų išlaikymui, tokiu atveju sveikatos būklè nebus objektyvia pareigos nevykdymo priežastimi.

Neretai teismų praktikoje išsakoma pozicija, kad baudžiamojon atsakomybèn netraukiamas asmuo, kuris atlieka laisvès atemimo bausmę $e^{43}$. Vis dèlto, nesinorètų visiškai pritarti šiai pozicijai, nes pats bausmès atlikimas nepašalina pareigos teikti išlaikymą vaikui. Autorès nuomone, kiekvienu konkrečiu atveju turi būti tikrinama galimybè dirbti ir uždirbti. Jeigu kaltininkas, atlikdamas bausmę, nedirba dèl to, kad nèra darbo vietų, tai jam negalime taikyti baudžiamosios atsakomybès.

Lietuvos teismų praktikoje stebima aiški tendencija sprendžiant patraukimo baudžiamojon atsakomybėn klausimą gana plačiai vadovautis kaltininko turtine padètimi,. Tai verčia teismą analizuoti asmens, kuriam ketinama taikyti baudžiamąją atsakomybę, finansinę situaciją, t. y. surinkti duomenis apie jo gaunamas pajamas, turimą turtą, ịsipareigojimus kreditoriams, išlaikomus asmenis, nedarbo priežastis, galimybes įsidarbinti, dirbti ir užsidirbti ir t. t., juos kompleksiškai įvertinti ${ }^{44}$. Tiesa, reikia pripažinti, kad tai ne visuomet daroma tinkamai: neretai pamirštama atsižvelgti ị kitas reikšmingas bylos aplinkybes, turtinei padéčiai nepagrịstai suteikiamas lemiamas vaidmuo ir / arba, atvirkščiai - visiškai neatsižvelgiama ị nukentèjusịjị, jo turtinę padètį, gyvenimo sąlygas, patiriamus išgyvenimus ir kt. Kaltininko turtinès padèties kriterijus jokiu būdu negali apskritai paneigti bei pašalinti jo atsakomybès, nes tai paprasčiausiai prieštarautų vaiko interesams.

Teismas vienoje byloje, įvertinęs surinktus duomenis apie kaltininko A. G. gauta uždarbi jam dirbant advokatu bei apie jo ir jo sutuoktinès D. G. turètas skolas Valstybinio socialinio draudimo fondo biudžetui, nesumokètas įmokas ị valstybés biudžeta nuo už advokato paslaugas gaunamu pajamų, taip pat Vilniaus miesto 2-ojo apylinkes teismo $2003 \mathrm{~m}$. sausio $3 \mathrm{~d}$. sprendimu iš D. G. priteista skola ir delspinigius UAB „Inžineriniai tyrinejimai" už patalpu, naudotu advokatu biurui, nuoma ir komunalines paslaugas, A. G. šeimos turètas skolas $U A B$ „Vilniaus energija“, UAB „Lazdynu būs-

41 Vilniaus miesto 1 apylinkès teismo 2011-03-31 nuosprendis baudžiamojoje byloje (bylos Nr. 1-193-203/2011).

42 Kauno apygardos teismo Baudžiamụjų bylų skyriaus teisèjų kolegijos 2008-11-11 nutartis baudžiamojoje byloje (bylos Nr. 1A-605-348/2008).

43 Žr., pvz., Lietuvos Aukščiausiojo Teismo Baudžiamųjų bylų skyriaus trijų teisėjų kolegijos 2007-11-20 nutartis baudžiamojoje byloje (bylos Nr. 2K-695/2007).

44 Žr., pvz., Kauno miesto apylinkès teismo 2012-05-03 nuosprendis baudžiamojoje byloje (bylos Nr. 1-422-593/2012). 
tas" už būsto išlaikymą, pripažino, kad inkriminuojamos nusikalstamos veikos laikotarpiu A. G. materialine padètis buvo sunki. Teismas padare išsadą, kad A. G. tam tikrais laikotarpiais nevykdè pareigos išlaikyti vaiką, dèl sunkios materialinès padèties, neturedamas realios galimybès ja vykdyti ${ }^{45}$.

Pripažįstant, kad sunki turtine padètis lèmè teismo sprendimo išlaikyti vaiką nevykdymą, turi būti ịvertintos priežastys, dèl kurių kaltininko turtinė padètis yra sunki, t. y. ištirtos aplinkybès, nulemusios komplikuotą finansinę būklę, tų aplinkybių objektyvumas ir subjektyvumas, veikimo trukmé, o svarbiausia - ar sunki finansiné padètis buvo nulemta paties asmens veiklos ir kokios, ar vis dèlto susiklostè dèl nuo jo nepriklausančių veiksnių. Autorès nuomone, ị sunkią kaltininko turtinę padètị reikètų atsižvelgti tik tais atvejais, jei ji būtų arba taptų sunki ar labai komplikuota, kai teismo sprendimo vykdymas taptų nepakeliama finansine našta. Todèl abejonių kelia minètame pavyzdyje teismo išsakytas advokato veikos traktavimas. Vargu ar vien ta aplinkybè, kad kaltininkas turi skolų tretiesiems asmenims, gali lemti išvadą apie sunkią turtinę padètį. Esant tokiai teisinei situacijai, kai kaltininkas, turintis išlaikymo įsiskolinimą, turi ir kitų skolų tretiesiems asmenims, vaiko išlaikymas turi nusverti kitų kreditorių reikalavimus. Kaltininko skolos nelaikytinos svarbia išlaikymo neteikimo priežastimi. Sunki tèvų turtine padètis yra pateisinama tik retais ir išimtiniais, nepriklausančiais nuo kaltininko valios atvejais. Kaltininkams ị sunkią turtinę padètị patekus dèl savo elgesio (nuolatinio girtavimo, turto švaistymo ir kt.), jie negali remtis susidariusia sunkia turtine padetimi kaip aplinkybe, šalinančia veikos pavojingumą.

Turtinè padètis negali būti esminis kriterijus nustatant vengimo išlaikyti vaiką nusikaltimo buvimą: tai, kad nuteistasis turéjo mokèti paskola ar gavo nedideles pajamas, neatleido jo nuo pareigos teikti vaikams išlaikyma, kuris atsižvelgiant i faktinị jo dydị ir taip yra minimalus, todè šios aplinkybès negali büti vertinamos kaip priežastys, šalinančios baudžiamaja atsakomybę ${ }^{46}$.

Pavyzdžiai iš Lietuvos teismų praktikos rodo, kad nagrinèjant vengimo išlaikyti bylas vadovaujamasi realios arba sukeliamos tokios žalos grèsmés (padariniu) kriterijumi. Žalos požymio panaudojimas neretai tampa būtinu, kad būtų tvirčiau argumentuojama viena ar kita pozicija. Teismai konstatuoja, kad vaiko materialine padètis yra sunki ${ }^{47}, k a d$ už pervedamus 10 Lt neįmanoma patenkinti minimaliu bütiniausių vaiko poreikiu bei išlaikyti augantị vaikq̨ ${ }^{48}$ vaikams negavus išlaikymo,

45 Lietuvos Aukščiausiojo Teismo Baudžiamųjų bylų skyriaus trijų teisejų kolegijos 2008-02-19 nutartis baudžiamojoje byloje (bylos Nr. 2K-124/2008).

46 Kauno apygardos teismo Baudžiamụjų bylų skyriaus teisèjų kolegijos 2013-06-17 nutartis baudžiamojoje byloje (bylos Nr. 1A-437-579/2013).

47 Žr., pvz., Klaipėdos apygardos teismo Baudžiamųjų bylų skyriaus teisèjų kolegijos 2012-0419 nutartis baudžiamojoje byloje (bylos Nr. 1A-245-380/2012); Klaipédos apygardos teismo Baudžiamųjų bylų skyriaus teisėjų kolegijos 2012-11-08 nutartis baudžiamojoje byloje (bylos Nr. 1A-904-174/2012).

48 Šiaulių apygardos teismo Baudžiamųjų bylų skyriaus teisèjų kolegijos 2013-01-21 nutartis baudžiamojoje byloje (bylos Nr. 1A-74-282/2013). 
motina ne tik negavo lèšu ju išlaikymui, bet ir vykdè ne tik savo, bet ir tévo pareiga ${ }^{49}$ ir pan. Padarinių, o geriau sakytina - žalos atsiradimo kriterijus yra labai svarbus. BK 164 straipsnyje numatyto nusikaltimo sudètis formali, tačiau istatymų leidejjas baudžiamąją atsakomybę už vengimą išlaikyti vaiką nustatė ne tiek dẻl pačios veikos pavojingumo, kiek dèl veikos padarymo galinčių atsirasti žalingų padarinių vaikui negavus lèšų pragyvenimui. Kartu pažymètina, kad padarinių kaip būtinojo požymio neịtvirtinimas nusikalstamos veikos sudètyje nereiškia, jog veikos, BK aprašytos formaliosiomis sudètimis, nesukelia pavojingų padarinių ir kad jų apskritai nereikia tirti bylose. Sprendžiant BK 164 straipsnio taikymo klausimą, atsižvelgtina ir ị tai, ar šiuo nusikaltimu buvo padaryta žala, padarytos žalos pobūdị ir dydį. Reikètų atsižvelgti ne tik ị žalos piniginę išraišką (ịsiskolinimo dydị), bet ir ị nukentèjusijjît, jo turtinę padètị, gyvenimo sąlygas, patiriamus išgyvenimus ir kt. Pavydžiui, nukentėjusiajam, kurio materialinė padètis yra sunki, žala gali būti pripažįstama ir tokia žala, kuri pagal jos piniginę išraišką nèra didelè.

BK 164 straipsnyje vartojamas terminas „vengimas“ reiškia ne ką kita kaip veikos pastovuma, nuolatini jos pobūdį. Nusikaltimo buvimą rodo dažnas veikos pasikartojimas. Autorès nuomone, vengimas pasižymi tam tikru sistemingumu, kuris laikytinas kitu svarbiu atribojimo kriterijumi. Vienkartiniai, smulkūs ar neesminiai kaltininko pareigos išlaikyti vaiką pažeidimai neturètų suponuoti asmens traukimo baudžiamojon atsakomybèn pagal BK 164 straipsnị. Teisinèje literatūroje paprastai veika laikoma sisteminga, kai pasikartoja ne mažiau nei tris kartus. Matyt, turint galvoje grynai lingvistinę prasmę, teisinèje literatūroje atsirado aiškinimas, kad vengimu išlaikyti vaiką laikytini atvejai, kai kaltininkas tris mènesius iš eilès arba tris mènesius per metus vengia mokèti alimentus arba moka tik dali jų ú $^{50}$. Toks aiškinimas kokiame nors kitame teisiniame kontekste galbūt nekeltų abejonių, tačiau nagrinejjamai normai jis nèra visiškai tinkamas. Kadangi išlaikymo vaikui teikimas turètų būti sprendžiamas pirmiausia civilinio proceso tvarka, tai, autorès nuomone, veikos trukmè turi būti ne mažesnè kaip šeši mėnesiai. Apžvelgus teismų sprendimus šios kategorijos bylose, akivaizdu, kad veikos pastovumas, nuolatinumas, sistemingumas nèra siejamas vien su faktiniu laiko tarpu, bet ir su kitomis aplinkybėmis (pvz., vaiko amžiumi, kylančia žala ir kt.). Pažymėtina, kad BK 164 straipsnyje numatyta baudžiamoji atsakomybė ne už veiksmą - vengimą, bet už būseną kaip trunkamąjị nusikaltimą.

Teismų praktikoje diskutuojama, ar prie būtinųjų vengimo išlaikyti požymių priskirtinas piktybiškumas. Lietuvos Aukščiausiasis Teismas 2006-02-14 nutartyje baudžiamojoje byloje Nr. 2K-129/2006 išaiškino, kad baudžiamas tik piktybinis vengimas išlaikyti vaikus, tačiau kitose bylose paneigè būtinumą ịrodinèti ši baudžiamajame įstatyme nenumatytą požymį ${ }^{51}$. Subjektyvųji vengimo išlaikyti vaiką elementą

49 Šiaulių apygardos teismo Baudžiamųjų bylų skyriaus teisèjų kolegijos 2012-02-27 nutartis baudžiamojoje byloje (bylos Nr. 1A-68-519/2012).

50 Žr., pvz., Pudovochkin, Ju. E., supra note 32, p. 222.

51 Lietuvos Aukščiausiojo Teismo Baudžiamųjų bylų skyriaus trijų teisèjų kolegijos 2007-02-13 nutartis baudžiamojoje byloje (bylos Nr. 2K-65/2007). 
nusako kaltininko veikimas tyčia, t. y. kaltininkas sąmoningai nevykdo pareigos. Piktybiškumo požymis apibūdina didesnị kaltininko smerktinumą, nes tai parodo jo veikos kryptingumą, kaltininko požiūrị. Šio kriterijaus svarbą pagrịsti padeda atsakymas ì klausimą, kodèl kaltininkas tai daro. Kiekvienu konkrečiu atveju teismas vertina, kodèl kaltininkas neteikia išlaikymo, kokias deda pastangas gauti reikiamas lešas ir t. t. Priežastys, kodèl jis vengia išlaikyti vaiką, ką daro su lěšomis, skirtomis vaikui išlaikyti, yra svarbios sprendžiant veikos pavojingumo klausimą. Piktybiškumas nèra tik subjektyvusis kriterijus, kuris parodo kaltininko psichines nuostatas (piktą valią, neapykantą, atkaklumą, ignoravimą ir kt.), bet taip pat rodo veikos padarymo būdą. Piktybiškumas yra objektyvusis-subjektyvusis kriterijus, kuris atskleidžia tiek kaltininko elgesĭ, tiek jo požiūrị. Piktybiškumas kaip požymis apima veikos nuolatinumą ir trukimą ilgą laiką. Piktybiškumo požymio taikymas labai sustiprina teismo sprendimo argumentaciją, todèl tai laikytina papildomu kriterijumi.

Nepaisant gana plataus vengimo veikos suvokimo, pažymètina, kad vengimas, kaip teisinis požymis, nèra vienareikšmis ir pavojingumo prasme gali turèti labai skirtingų formų, todèl negali būti nustatinejjamas ir pripažịstamas automatiškai. Kreditoriaus teisinès padèties apsunkinimo kriterijus yra pagrindinis kriterijus, atribojantis vengimą išlaikyti vaiką nuo civilinès teisès pažeidimų. Tačiau baudžiamoji atsakomybé pagal BK 164 straipsnii turètu atsirasti tuo atveju, kai asmens turtine padètis ir darbingumas, padaryto pažeidimo pobūdis, neveikimu padaryta žala ar potenciali žala, trukmè, piktybiškumas iš tikrųjų leidžia spręsti apie didelị tokio neveikimo pavojingumą ir reikšmingą šia teisès norma saugomo objekto paneigimą.

\section{Išvados}

1. Vengimo išlaikyti vaiką kriminalizavimą nulèmė egzistuojanti opi socialinė problema ir poreikis ją spręsti. Nusikaltimo sudetis nepasižymi sklandžia teisine technika, tačiau vengimas išlaikyti vaiką negali būti dekriminalizuotas, nes civilinès teises priemonių nepakaktų apsaugant nukentejusių vaikų interesus. Baudžiamoji atsakomybè yra efektyvus būdas kovoti su kaltininkais, vengiančiais teikti išlaikymą vaikui, tačiau tai neturi būti vertinama kaip pagrindinè, esminè priemonè spręsti tokio pobūdžio klausimus. Tai reiškia, kad baudžiamoji atsakomybè turi būti taikoma tik išimtiniais atvejais, kai neįmanoma panaudoti švelnesnių (civilinio ar administracinio proceso) priemonių.

2. Užsienio šalių baudžiamuosiuose įstatymuose pareigos išlaikyti vaiką nevykdymas pripažistamas nusikalstamu. Užsienio valstybių baudžiamuosiuose i̇statymuose įtvirtinti vengimo išlaikyti vaiką atribojimo kriterijai (padariniai, veikos padarymo būdas, trukmè) plačiai taikomi ir Lietuvos teismų praktikoje.

3. Vengimo išlaikyti vaiką nusikaltimo sudètis pagal aprašytus požymius yra nepakankamai konkreti, nes vengimo požymis nerodo didesnio veikos pavojingumo ir nèra tinkamas atribojimo kriterijus. Šios kategorijos bylose baudžiamajai ir civilinei atsakomybei atriboti veiksmingas yra kreditoriaus teisinès padèties apsunkini- 
mo kriterijus. Tačiau baudžiamoji atsakomybè pagal BK 164 straipsnị turètų atsirasti tuo atveju, kai asmens turtinè padètis ir darbingumas, padaryto pažeidimo pobūdis, neveikimu padaryta žala ar potenciali žala, trukmé, piktybiškumas iš tikrųjų leidžia spręsti apie didelị tokio neveikimo pavojingumą ir reikšmingą šia teisès norma saugomo objekto neigimą.

\section{Literatūra}

Abramavičius, A., et al. Lietuvos Respublikos baudžiamojo kodekso komentaras. Specialioji dalis (99-212 straipsniai). Vilnius: VIt Registrų centras, 2009.

Bertel, Ch.; Schwaighofer, K. Österreichisches Strafrecht Besonderer Teil II (\$\$ 169 bis 321 StGB). Wien, NewYork: Springer. 2010.

Bernikov, P. V. Ugolovnaja otvestvennost za neuplatu alimentov kak zashhita prav cheloveka. [Criminal liability for failure to pay child support as protection of human rights]. [interaktyvus]. [žiūrèta 2013-07-04]. <http:// www.law.edu.ru/doc/document. asp?docID $=1193708>$.

Criminal Code of the Republic of Estonia [interaktyvus]. [žiūrèta 2013-07-04]. $<$ ttp://legislationline.org/documents/ section/criminal-codes $>$.

Criminal Code of the French Republic [interaktyvus]. [žiūrèta 2013-07-04]. $<$ http://www.legislationline.org/documents/section/criminal-codes $>$.

Criminal Code of the Federal Republic of Germany [interaktyvus]. [žiūrèta 201110-20] <http://www.gesetze-im-internet.de/englisch_stgb/englisch_stgb. html\#StGBengl_000P171>.

Criminal Code of the Republic of Latvia [interaktyvus]. [žiūrèta 2013-07-04]. $<$ ttp://legislationline.org/documents/ section/criminal-codes $>$.

Criminal Code of the Republic Poland [interaktyvus]. [žiūrèta 2011-10-20]. <http://www.legislationline.org/ru/ documents/action/popup/id/16287/ preview $>$.

Criminal Code of the Slovak Republic [interaktyvus]. [žiūrèta 2013-07-04]. $<$ http://legislationline.org/documents/ section/criminal-codes $>$.

Ermolaev, A. V. Ugolovnaja otvestvennost za prestuplenija protiv semi: problemy zakonodatelnoj reglamentacii $i$ pravoprimenenija i puti ik razreshenija. Avtoreferat dissertacii. [Criminal responsibility for crimes against the family: the problems of legislative regulation and enforcement, and ways of solving them]. Krasnodar, 2009.

Fedosiuk, O. Paskaitų tezès [interaktyvus]. [žiūrèta 2013-07-04]. <http://www. mruni.lt/lt/TF_btk.htm $>$.

Kanteeva, E. V. Aktualnye problemy pravoprimenitelnoj praktiki pri vyjavlenii i prizvodstve doznanija po prestuplenijam, predusmotrennym st. 157 Ugolovnogo kodeksa Rossijskoj Federacii (na primere Respubliki Mordovija). Vestnik Cheljabinskogo gosudarstvennogo universiteta. [Bulletin of the Chelyabinsk State University]. 2013, 5 (296).

Kauno apygardos teismo Baudžiamųjų bylų skyriaus teisèjų kolegijos 2008-1111 nutartis baudžiamojoje byloje (bylos Nr. 1A-605-348/2008).

Kauno miesto apylinkès teismo 2012-0503 nuosprendis baudžiamojoje byloje (bylos Nr. 1-422-593/2012).

Kauno apygardos teismo Baudžiamųju bylų skyriaus teisèjų kolegijos 2013-06- 
17 nutartis baudžiamojoje byloje (bylos Nr. 1A-437-579/2013).

Klaipèdos apygardos teismo Baudžiamųjų bylų skyriaus teisèjų kolegijos 2012-0419 nutartis baudžiamojoje byloje (bylos Nr. 1A-245-380/2012).

Klaipèdos apygardos teismo Baudžiamųjų bylų skyriaus teisèjų kolegijos 2012-1108 nutartis baudžiamojoje byloje (bylos Nr. 1A-904-174/2012).

Kodeks karny. Część szczególna. Tom I. Komentarz do artykułów 117-221. Pod redakcja A. Wąska, R. Zawłockiego. Wydawnictwo C.H. Beck, 2010.

Kolakowska-Przelomiec, H. Przestępstwa niealimentacji - studium kryminologiczne. Wrocław: zakład Narodowy im. Ossolińskich, 1989.

Lietuvos Aukščiausiojo Teismo Baudžiamųjų bylų skyriaus trijų teisejjų kolegijos 2007-11-20 nutartis baudžiamojoje byloje (bylos Nr. 2K-695/2007).

Lietuvos Aukščiausiojo Teismo Baudžiamųjų bylų skyriaus trijų teisèjų kolegijos 2008-02-19 nutartis baudžiamojoje byloje (bylos Nr. 2K-124/2008).

Lietuvos Aukščiausiojo Teismo Baudžiamųjų bylų skyriaus trijų teisèjų kolegijos 2007-02-13 nutartis baudžiamojoje byloje (bylos Nr. 2K-65/2007).

Lietuvos TSR baudžiamojo kodekso komentaras. Vilnius: Mintis, 1989.

Österreich Strafgesetzbuch. [interaktyvus]. [žiūrèta 2011-10-20] <http://www. jusline.at/Strafgesetzbuch_(StGB). html>.

Pudovochkin, Ju. E. Otvetstvennost $z a$ prestuplenija protiv nesovershennoletnik po Rossijskomu ugolovnomu pra$v u$. [Responsibility for crimes against minors under Russian criminal law]. Санкт-Петербург, 2002, p. 204.

Pranka, D. Nusikalstamos veikos ir civilinès teisès pažeidimo atribojimo kon- cepcija Lietuvos baudžiamojoje teisejje. Daktaro disertacija. Socialiniai mokslai (teisè). Vilnius: Mykolo Romerio universitetas, 2012.

Siwik, Z. Przestepstwo niealimentacji ze stanowiska polityki kryminalnej. Wrocław: Państwowe Wydawn. Nauk., 1974. Statistiniai duomenys apie ikiteisminio tyrimo įstaigose $2013 \mathrm{~m}$. užregistruotus nukentejusius vaikus (iki 18 metų) pagal atskiras nusikalstamas veikas: BK 160 164 straipsniai. Informatikos ir ryšiu departamentas [interaktyvus]. Vilnius [žiūrèta 2014-03-07]. <http://www.ird. lt/infusions/report_manager/reports/ txt_file.php?fv=data/1_201312_lt/f50n-iti-201312.data.txt\&ff $=\% 3 \mathrm{C}$ ! |50N-ITI|13|--\%3E\&tt=Duomenys\%20 a pie $\% 20$ ikiteis minio $\% 20$ tyrimo $\% 20 \%$ C $4 \%$ A F s ta ig o se $\% 20$ u\%C5\%BEregistruotus\%20nukent\% C $4 \% 97$ jusius $\% 20$ vaikus $\% 20 \%$ 28iki\%2018\%20met\%C5\%B3\%29\%20 \%3C\%2Fstrong\%3E\%28remiantis\%20 i\% C5\% A 1 ankstiniais \%20duomenimis\%29\%20\%3Cstrong\%3E\%28Forma_ 50N-IT\%C4\% AE\%29>.

Solomon-Fears, C.; Smith, A. M.; Berry, C. Child Support Enforcement: Incarceration As the Last Resort Penalty For Nonpayment of Support. The Green Book [interaktyvus]. [žiūrèta 2013-0724]. <http://greenbook.waysandmeans. house.gov/sites/greenbook.waysandmeans.house.gov/files/2012/documents/R42389_gb.pdf>.

Šiaulių apygardos teismo Baudžiamųjų bylų skyriaus teisėjų kolegijos 2012-1227 nutartis baudžiamojoje byloje (bylos Nr. 1A-1212-152/2012).

Šiaulių apygardos teismo Baudžiamųjų bylų skyriaus teisėjų kolegijos 2013-0121 nutartis baudžiamojoje byloje (bylos Nr. 1A-74-282/2013). 
Šiaulių apygardos teismo Baudžiamųjų bylų skyriaus teisejų kolegijos 2012-0227 nutartis baudžiamojoje byloje (bylos Nr. 1A-68-519/2012).

Tarybine baudžiamoji teise. Ypatingoji dalis. Vilnius: Mintis, 1974, p. 119.

Ugolovnyj kodeks Respubliki Belarusj [Criminal Code of the Republic of Belarus]. [interaktyvus]. [žiūrèta 201307-04]. < http://www.wipo.int/wipolex/en/details.jsp?id=10048>.

Ugolovnyj kodeks Belgii. [Criminal Code of Belgium]. Sankt-Peterburg: juridicheskij centr press, 2004.

Ugolovnyj kodeks Rossijskoj Federacii. [Criminal Code of the Russian Federation] [interaktyvus]. [žiūrèta 2013-0704] <http://www.legislationline.org/ru/ documents/action/popup/id/16287/ preview $>$.

Ugolovnyj kodeks Ukrainy. [Criminal Code of Ukraina] [interaktyvus]. [žiūrèta 2013-07-04] .<http://kodeksy. com.ua/ka/ugolovnyj_kodeks_ukraini/ statja-164.htm >.

Vaikų išlaikymo fondo ịstatymo ex-post poveikio vertinimas. Lietuvos Respublikos Vyriausybe [interaktyvus]. Vilnius [žiūrèta 2013-06-26]. <http://www.lrv.
lt/bylos/VORTprojektas/Dokumentai/8-VIF\%20Vertinimas\%20final. pdf $>$.

Vilniaus miesto 1 apylinkès teismo 201205-17 nuosprendis baudžiamojoje byloje (bylos Nr. 1-769-654/2012).

Vilniaus miesto 1 apylinkès teismo 201103-31 nuosprendis baudžiamojoje byloje (bylos Nr. 1-193-203/2011).

Varènos rajono apylinkès teismo 2013-0530 nuosprendis baudžiamojoje byloje (bylos Nr. 1-48-445/2013).

Vilniaus apygardos teismo Baudžiamųjų bylų skyriaus teisejų kolegijos 2013-0226 nuosprendis baudžiamojoje byloje (bylos Nr. 1A-203-92/2013).

Zimmermann, H. Strafanzeige wegen Unterhaltspflichtverletzung (\$170 Strafgesetzbuch - StGB) als Mittel der Durchsetz ung von Unterhaltsansprüchen? [interaktyvus]. [žiūrèta 2013-07-24]. <http://www.zimmermann-strecker.de/themen/pdf/2008_12_Unterhaltspflichtverletzung.pdf $>$.

Žalnieriūnas, L.; Girdenis, T. Vengimo išlaikti vaiką probleminiai kvalifikavimo aspektai ir alternatyvūs normai instrumentai. Jurisprudencija. 2013, 20(2).

\title{
EVASION OF CHILD'S MAINTENANCE AND THE PROBLEMS OF ITS CRIMINAL LEGAL EVALUATION
}

\author{
Kristina Grinevičiūtè \\ Mykolas Romeris University, Lithuania
}

Summary. Lithuanian Law provides criminal liability for evasion of child's maintenance (Article 164 of the CC). This norm directly criminalizes civil law breach, i.e. such crime allows punishing for debts (debt for child's maintenance, occurred on the basis of court decision). In practice, non-fulfillment of the court decision of child's maintenance raises a number of questions, whereas it is not clear from which moment the person is held criminally liable and when it is enough to apply other techniques. The criteria of predetermining convicting of a person are not clear. This article analyzes the evasion of 
child's maintenance and the problems of its criminal legal evaluation. The objective of the article is to define criminal liabilities for evasion of child's maintenance according to court decision criteria on the basis of systematic, logical court practice analysis.

Evasion of child's maintenance is predetermined by the existing social problem and its solution demand. Crime does not distinguish itself with smooth legal technique, however, the evasion of child's maintenance cannot be categorically excluded (decriminalized), whereas civil law means are insufficient to defend interests of aggrieved children. Criminal liability is an efficient method to deal with criminals, evading child's maintenance, however, this shall not be evaluated as a principal, efficient measure for solution of such type of issues. This means that criminal liability shall be applied only in exceptional cases, when it is impossible to apply lenient measures (of civil or administrative procedure).

In criminal codes of foreign countries non-fulfillment of the duty to maintain a child has an individual legal meaning and is considered a crime. Criteria of evasion of child's maintenance (consequences, crime commission method, duration, etc.), established in criminal codes of foreign countries, are also widely applicable in practice of Lithuanian courts.

Components of crime related to evasion of child's maintenance are noninformative, according to the described essential elements, as this essential element does not demonstrate greater hazard of the act and is improper restriction criterion. Credit legal status aggravating criterion is highly efficient for restriction of criminal and civil liability in cases referred to in this category. However, according to Article 164 of the CC, criminal liability shall occur in case if the person's property status and ability to work, nature of the breach, damage sustained due to failure to act or potential damage, duration, abuse really allow deciding on great hazard of such inactivity and significant negation of the object defended by this legal norm.

Keywords: evasion, child maintenance, child, criminal liability, criminalization.

Kristina Grinevičiūtė, Mykolo Romerio universiteto Teisès fakulteto Baudžiamosios teisès ir proceso instituto lektorè. Mokslinių tyrimų kryptys: nusikaltimai ir baudžiamieji nusižengimai vaikui ir šeimai.

Kristina Grinevičiūtè, Mykolas Romeris University, Faculty of Law, Institute of Criminal Law and Procedure, lecturer. Research interests: crimes and misdemeanors against child and family. 